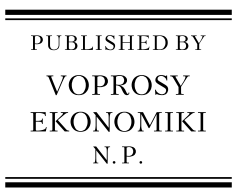

\title{
Foreword \\ The Russian economy in comparative perspective
}

From June 15-17, 2017, the Saint Petersburg campus of the National Research University Higher School of Economics hosted the Second World Congress of Comparative Economics co-organized by the European Association for Comparative Economic Studies (EACES), Association for Comparative Economic Studies (ACES), Japanese Association for Comparative Economic Studies (JACES), Korean Association for Comparative Economic Studies (KACES), European Association for Evolutionary Political Economy (EAEPE), Chinese Economist Society (CES), Society for the Study of Emerging Markets, and Italian Association for Comparative Economic Studies (AISSEC).

This was the second academic event organized jointly by the leading world associations of comparative economic studies. The First World Congress of Comparative Economics was held in Rome in June 2015.

The Second Congress's leading theme was the "Revolution and Evolution in Economic Development," referring to the $100^{\text {th }}$ anniversary of two revolutions in Russia in 1917. It consisted of three plenary sessions (and three keynote addresses) and 91 parallel sessions, in which about 350 papers were presented. The submitted papers covered topics such as growth catch up, business and financial cycles, structural transformation, corporate governance, economic history, migration, foreign direct investment, financial and banking sector, human capital development, industrial organization, institutional design and dynamics, labor market and industrial relations, macroeconomic stability and policies, regional development, international trade, and trade policies. Geographically, they related to various countries or group of countries, both advanced economies and emerging markets.

However, given the Congress's topic and venue, it was no surprise that a substantial portion of the submitted papers dealt with historical and contemporary problems of the Russian economy or with cross-country comparative analyses in which Russia served as a prominent reference point. This helped us prepare this special issue of the Russian Journal of Economics titled "The Russian economy in comparative perspective." It includes seven papers presented at the Congress. They analyze various aspects of the Russian economy, economic policy, and economic and institutional reforms in Russia and compare them with other countries. 
The issue opens up with Alexander Auzan's short essay "Revolutions and evolutions in Russia: In search of a solution to the path dependence problem," which constitutes an expanded version of his keynote address (under the same title) delivered to the Congress. It refers directly to the Congress's central theme on revolutions and evolutions in the dramatic context of Russian economic, political, and institutional history. The author's main concern is the tendency to reproduce the old authoritarian institutions throughout Russian history and how to get out of this institutional trap.

The introductory essay is followed by two macroeconomic policy papers. In the first, "Sources of long run economic growth in Russia before and after the global financial crisis," Ilya Voskoboynikov provides an analysis using conventional industry growth accounting. He found that the stagnation of 2008-2014 was more the outcome of total factor productivity (TFP) slowdown and the deterioration of the allocation of labor rather than the shortage of capital inputs. Moreover, TFP slowdown started in Russia a few years before the crisis, the same as in major global economies such as the United States, OECD countries, China, and Brazil.

In the second paper ("Breaking monetary policy rules in Russia"), Iikka Korhonen and Riikka Nuutilainen detected, by means of econometric analysis, the key turning points in Russia's monetary policy in the critical period of changing its strategy towards inflation targeting. They confirmed that Russia's monetary policy could be characterized by the Taylor rule at least since 2006. Furthermore, there were two breaks in the coefficients of the estimated monetary policy rule, possibly signifying a a shift towards traditional inflation targeting but also reflecting the recent economic turbulence.

The remaining four papers deal with microeconomic and institutional issues. In the first, "Analysis of debt burden in Russian economy sectors," Svetlana Popova, Nataliya Karlova, Alexey Ponomarenko, and Elena Deryugina conducted an empirical analysis with the use of a regression model that included both the fundamental explanatory variables of companies and industry fixed effects. They came to the conclusion that standard variables such as profitability, company size, asset turnover, and fixed-asset turnover ratio had a strong statistical significance but did not fully explain variation in the companies' debt levels. There were also other, industry-specific factors at work.

Evsey Gurvich and Elena Vakulenko in their study "Macroeconomic and structural properties of the Russian labor market: A cross-country comparison" examined empirically various theoretical models of labor market behavior in Russia and compared their results with those of other advanced and emerging-market economies. They established that the Russian labor market could be characterized by a combination of serious structural problems (such as low employee mobility, the significant size of the shadow sector, etc.) and good macroeconomic performance illustrated by high elasticity of real wages relative to unemployment.

In the paper "Factors determining intra-regional fiscal decentralization in Russia and the US," Michael Alexeev and Arseny Mamedov employed various econometric specifications to estimate and compare the determinants of fiscal decentralization in the two countries. They found that while the factors of decentralization in the US largely conformed to existing theoretical predictions, this was not the case in Russia, where their results differed even from those of 
earlier similar studies. This was probably the effect of the decline of democratic institutions in Russia's regions and overall political and economic centralization in the country.

Finally, Wladimir Andreff and Madeleine Andreff present the comparative study "Multinational companies from transition economies and their outward foreign direct investment." This is one of the few studies on outward foreign direct investment (FDI) in the region; the prevailing stream of literature concentrates on inward FDI. Needless to say, Russian companies play a prominent role in this process. The results presented in this paper showed that outgoing FDI was determined by the home country's level of economic development, the size of its home market, and its rate of growth, as well as technological variables: outgoing FDI decreased with an increase in the number of scientists in the home economy and with an increasing share of high-tech products in overall export, exhibiting a negative technological gap in transition economies. A lagged relationship between outward FDI and previous inward FDI suggests that Mathews' linkageleverage-learning theory is relevant in the case of transition economies.

As the guest editor of this issue, I would like to thank the authors for the editorial work done on their papers, as compared with their earlier versions presented at the Congress. Special words of gratitude are owed to the distinguished scholars who accepted the role of referees. Their critical opinions and comments helped the authors improve their papers and assisted me in making publication choices.

\author{
Marek Dabrowski \\ professor, Higher School of Economics, Moscow, Russia \\ non-resident fellow at Bruegel, Brussels, Belgium \\ fellow at CASE - Center for Social and Economic Research, Warsaw, Poland \\ E-mail: mdabrowski@hse.ru
}

